\title{
Aesthetic Rehabilitation of Enamel Hypomineralization with Microabrasion and Direct Composites (18 Month-Follow-up Report)
}

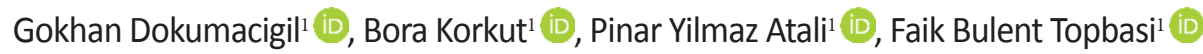 \\ ${ }^{1}$ Marmara University, Faculty of Dentistry, Department of Restorative Dentistry, Istanbul, Turkey.
}

Correspondence Author: Bora Korkut

E-mail: bora.korkut@marmara.edu.tr

Received: 16.05.2018 Accepted: 12.11.2018

\begin{abstract}
Objective: This case report represents a direct, prepless treatment of discolored anterior teeth due to Molar-Incisor Hypomineralisation (MIH) defect following microabrasion and vital bleaching.

Methods: Following clinical and radiological examinations, the discolored, teeth were microabraded with a microabrasive agent containing 6.6\% $\mathrm{HCl}$ (hydrochloric acid) and silicone carbide particles. Then the teeth were bleached by using $40 \%$ hydrogen peroxide. Finally direct composite restorations were performed with $\mathrm{A} 2$ shade. Polishing procedure was done by using polishing discs and spiral wheels.

Result: The restorations were evaluated in terms of retention, marginal integrity, marginal discoloration, anatomical form, secondary caries, surface texture, shade match, and postoperative sensitivity according to 'The Modified United States Public Health Service' (USPHS) criterias at 3rd, 9th and 18th months. Nevertheless, it was detected slight abrasion at 18-month follow-up on the labial surfaces of teeth \#11 and \#21, all the scores were considered as acceptable.

Conclusion: The microabrasion, vital bleaching and direct composite restoration combination is considered as a promising treatment method for MIH effected teeth under the conditions of this study.

Keywords: Microabrasion, Direct Composite, Bleaching, MIH, Aesthetic dentistry
\end{abstract}

\section{INTRODUCTION}

Tooth eruption begins after completing certain stages of development. During this phase, the formation of dental tissues; enamel, dentin and cement may not be fully completed due to some external or internal factors, resulting in developmental anomalies. The anomalies especially located at anterior region also causes some problems about aesthetics.

In this case report, a 21-year-old female patient applied to Marmara University faculty of Faculty of Dentistry, Department of Restorative Dentistry Clinic with unwilling aesthetic outlook due to discolorations on her anterior teeth (Figure 1). Clinical examination revealed hypomineralized sections were observed on labial surfaces of both maxillary and mandibular anterior dentition. Cavities and yellowbrown discolorations were observed in incisal thirds of maxillary canines and in middle thirds of maxillary central incisors, limited to enamel tissue (Figure 2). At radiographic examination no periapical lesions were detected and all the teeth were considered as vital. Minimally invasive preaparations followed by single shade composite veneers were selected as the treatment plan.

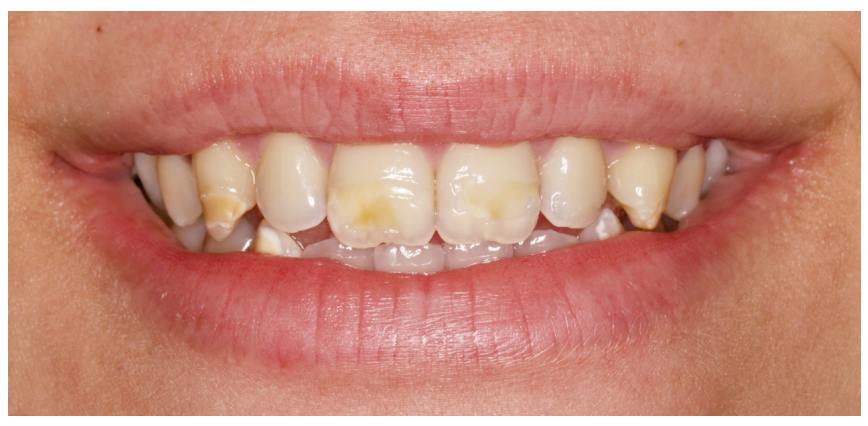

Figure 1. Initial (Extraoral)

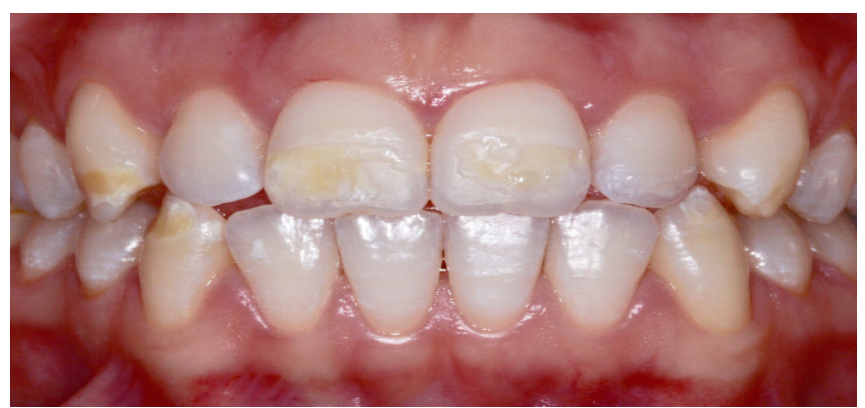

Figure 2. Initial (Intraoral) 


\section{METHODS}

At first appointment the teeth were isolated with rubber dam and microabrasion were applied to the teeth numbered 13, 11, 21, 43 with a microabrasive agent (Opalustre, Ultradent, USA) containing $6.6 \% \mathrm{HCl}$ (hydrochloric acid) and silicon carbide microparticles (Figure 3 ). The procedure was done at low speed for 60 seconds with a set of specially brushed tires and the cycle was repeated for 5 times. After applying a fluoride-containing polishing paste was applied on the teeth with low speed polishing tires, the rubber dam was removed and the teeth were cleaned (Figure 4). Vital office bleaching was done with an office bleaching agent (Opalescence Xtra Boost, Ultradent, USA) at the second appointment (Figure 5). Restorative treatment appointment was arranged after 2 weeks of bleaching procedure. Firstly the shade selection was considered by using button technique as A2 shade (Ceram- $X$ One, Dentsply, USA). Then the cavitated enamel surfaces were etched with $37.5 \%$ phosphoric acid (Gel Etchant, Kavo-Kerr, USA) for 30 seconds and the surfaces were rinsed and dried. A universal adhesive agent (Single Bond Universal, 3M ESPE, USA) was applied, slightly refined and polymerized for 20 seconds. A2 shade composite resin was applied to whole the prepared surfaces by free-hand layering technique (Figure 6). Surface finishing procedure was done by using a red-banded diamond burr in low speed under water cooling. In marginal contouring and interdental polishing, interdental polishing strips I different grain sizes (Epitex, GC, Japan) were used. Surface polishing procedure was done by using polishing discs (Optidisc, Kerr, USA) and and spiral polishing discs (Twist Dia, Kuraray, Japan) in different grains according to the manufacturer's guidelines. The patient was informed about oral hygiene and called for the recalls at 3, 9 and 18 months.

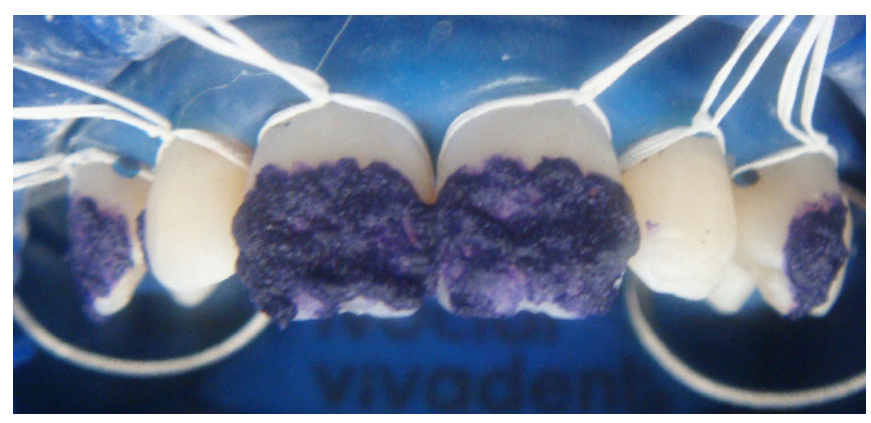

Figure 3. Microabrasion

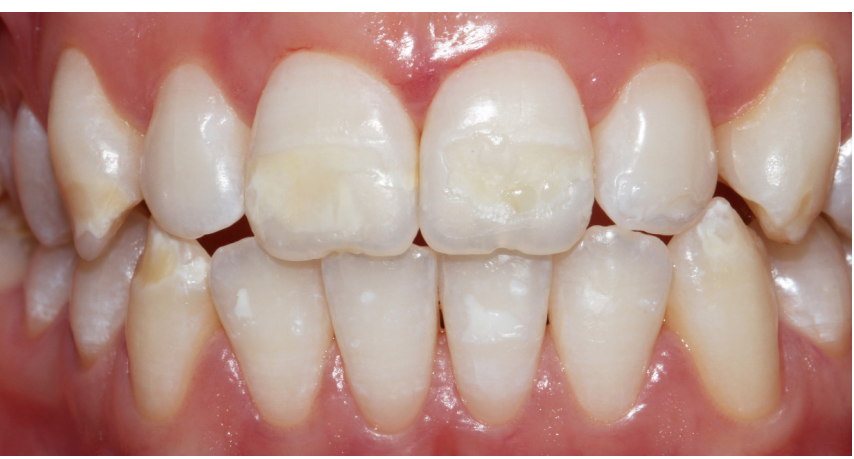

Figure 4. Immediate after microabrasion

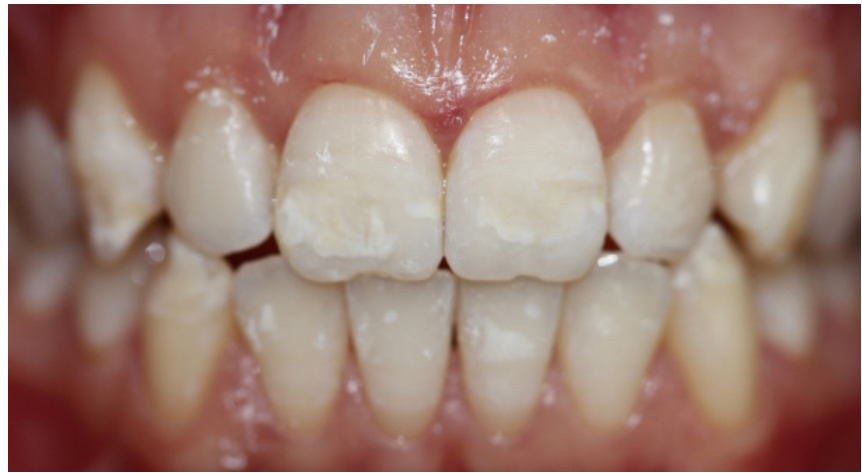

Figure 5. Immediate after vital bleaching

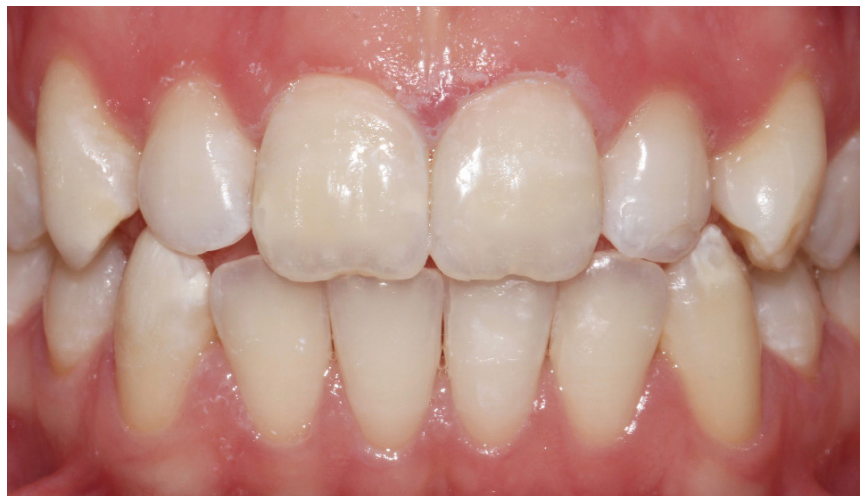

Figure 6. Immediate after the restorations

\subsection{Statistical Analysis}

The success rate of the restorations were evaluated according to the modified USPHS criterias in 3rd, 9th and 18th months recalls (Table 1 ).

\section{RESULTS}

The following outcomes were assessed; retention, marginal integrity, marginal discoloration, anatomical form, secondary caries, surface texture, shade match and postoperative sensitivity. As a result, at 3 (Figure 7) and 9-month-follow-ups (Figure 8), all the scores were acceptable as Alpha (A). All the restorations were considered as stable and compatible with the surrounding tissues in color and contour.

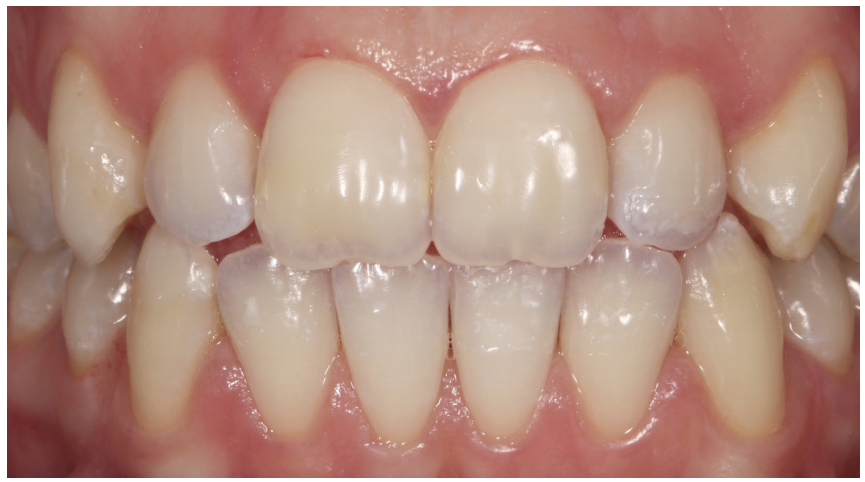

Figure 7. Three months follow-up 
Table 1. The Modified USPHS Criterias Scores of 3rd, 9th and 18th month follow-ups

\begin{tabular}{|c|c|c|c|c|c|}
\hline \multirow[t]{2}{*}{ Category } & \multirow[t]{2}{*}{ Scores } & \multirow[t]{2}{*}{ Criteria } & \multicolumn{3}{|c|}{$\begin{array}{l}\text { Re-call } \\
\text { (Month) }\end{array}$} \\
\hline & & & 3 & 9 & 18 \\
\hline RESTORATION & $\begin{array}{l}\text { Alpha (A) } \\
\text { Bravo (B) } \\
\text { Charlie (C) }\end{array}$ & $\begin{array}{l}\text { Restoration is present } \\
\text { Restoration is partially lost } \\
\text { Restoration absent }\end{array}$ & A & $A$ & A \\
\hline $\begin{array}{l}\text { MARGINAL } \\
\text { INTEGRITY }\end{array}$ & $\begin{array}{l}\text { Alpha (A) } \\
\text { Bravo (B) } \\
\text { Charlie(C) } \\
\text { Delta (D) }\end{array}$ & $\begin{array}{l}\text { Resin-enamel interface is } \\
\text { excellent; restoration closely } \\
\text { adapted to the tooth } \\
\text { No crevice is visible at } \\
\text { margins } \\
\text { Crevice at margin, enamel } \\
\text { exposed } \\
\text { Restoration is mobile, } \\
\text { fractured or missing }\end{array}$ & A & A & A \\
\hline $\begin{array}{l}\text { MARGINAL } \\
\text { DISCOLORATION }\end{array}$ & $\begin{array}{l}\text { Alpha (A) } \\
\text { Bravo (B) } \\
\text { Charlie (C) } \\
\text { Delta (D) }\end{array}$ & $\begin{array}{l}\text { No discoloration on the } \\
\text { margin between the } \\
\text { restoration and the tooth } \\
\text { structure } \\
\text { Slight staining can be polished } \\
\text { away } \\
\text { Obvious staining cannot be } \\
\text { polished away } \\
\text { Gross staining }\end{array}$ & A & A & A \\
\hline $\begin{array}{l}\text { ANATOMICAL } \\
\text { FORM }\end{array}$ & $\begin{array}{l}\text { Alpha (A) } \\
\text { Bravo (B) } \\
\text { Charlie (C) } \\
\text { Charlie (C) }\end{array}$ & $\begin{array}{l}\text { Restoration continuous with } \\
\text { existing anatomical form and } \\
\text { margins } \\
\text { Restoration is slightly } \\
\text { overcontured or oncontoured } \\
\text { Restoration is } \\
\text { undercontoured, dentin or } \\
\text { base exposed } \\
\text { Restoration is missing }\end{array}$ & A & A & A \\
\hline $\begin{array}{l}\text { SECONDARY } \\
\text { CARIES }\end{array}$ & $\begin{array}{l}\text { Alpha (A) } \\
\text { Charlie (C) }\end{array}$ & $\begin{array}{l}\text { No evidence of caries } \\
\text { contiguous with the margin of } \\
\text { the restoration } \\
\text { Caries evident contiguous } \\
\text { with the margin of the } \\
\text { restoration }\end{array}$ & A & $A$ & A \\
\hline $\begin{array}{l}\text { SURFACE } \\
\text { TEXTURE }\end{array}$ & $\begin{array}{l}\text { Alpha(A) } \\
\text { Bravo (B) } \\
\text { Charlie (C) } \\
\text { Delta (D) }\end{array}$ & $\begin{array}{l}\text { Smooth surface } \\
\text { Slightly rough or pitted } \\
\text { Rough, cannot be refinished } \\
\text { Surface deeply pitted, } \\
\text { irregular grooves }\end{array}$ & $A$ & A & B \\
\hline $\begin{array}{l}\text { SHADE } \\
\text { MATCH }\end{array}$ & $\begin{array}{l}\text { Alpha (A) } \\
\text { Bravo (B) } \\
\text { Charlie (C) } \\
\text { Delta (D) }\end{array}$ & $\begin{array}{l}\text { Restorations matches the } \\
\text { shade and translucency of } \\
\text { adjacent tooth structure } \\
\text { Discoloration between } \\
\text { restoration and tooth } \\
\text { structure within the normal } \\
\text { range of tooth } \\
\text { Discoloration between } \\
\text { restoration and tooth } \\
\text { structure outside the normal } \\
\text { range of tooth } \\
\text { Unacceptable color, shade } \\
\text { and translucency }\end{array}$ & $A$ & $A$ & $A$ \\
\hline $\begin{array}{l}\text { POSTOPERATIVE } \\
\text { SENTITIVITY }\end{array}$ & $\begin{array}{l}\text { Alpha (A) } \\
\text { Bravo (B) } \\
\text { Charlie (C) }\end{array}$ & $\begin{array}{l}\text { No postoperative sensitivity } \\
\text { Postoperative sensitivity } \\
\text { Postoperative sensitivity with } \\
\text { treatment need }\end{array}$ & $A$ & A & $A$ \\
\hline
\end{tabular}

Acceptable Scores: Alpha (A), Bravo (B); Unacceptable Scores: Charlie (C), Delta (D)
However at 18-month-follow-up, slight abrasions were detected on the labial surface morphology of teeth \#11 and \#21 and surface textures were scored as Bravo (B) (Figures 9 and 10). The restoration - tooth compatibility was also checked by using high contrast dental photography technique (Figure 11). Abraded surfaces on the restorations of both maxillary central incisors were approved. Moreover gloss retention of the same teeth was determined as low and in need of re-polishing comparatively.

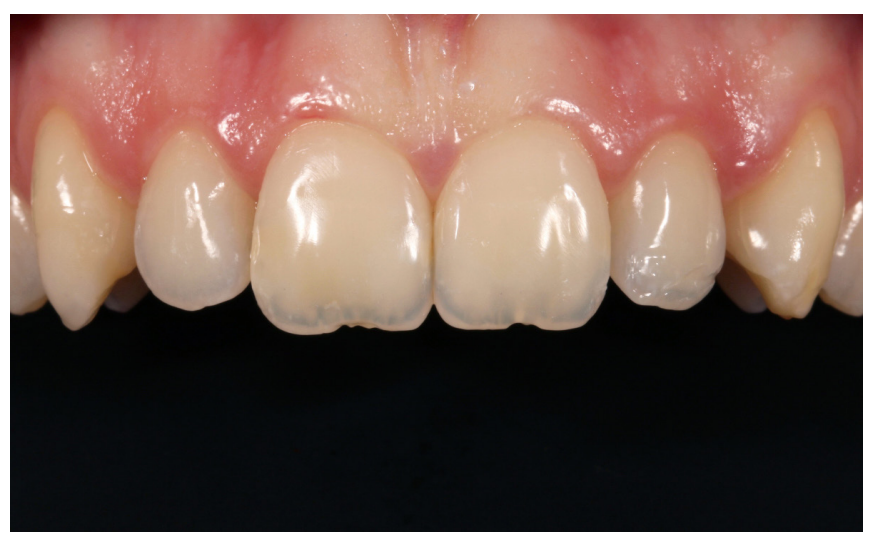

Figure 8. Nine months follow-up

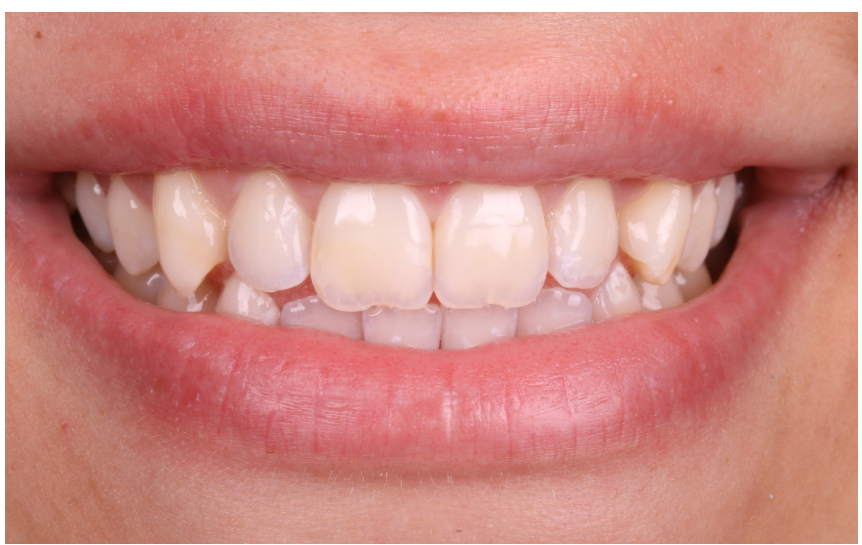

Figure 9. Eighteen months follow-up

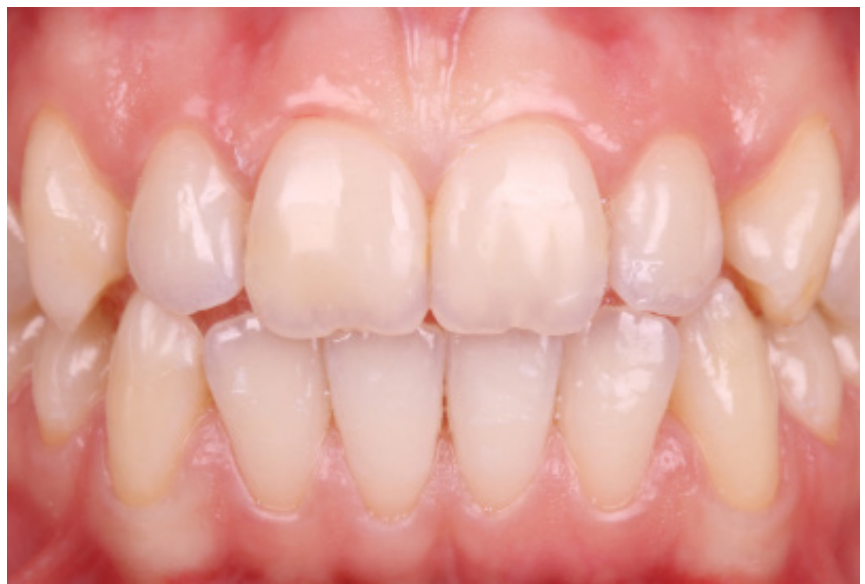

Figure 10. Eighteen months follow-up 


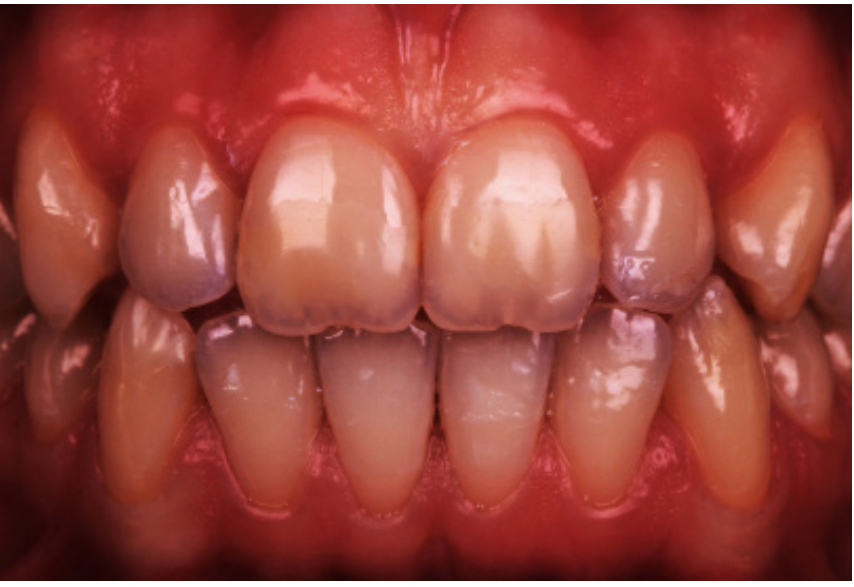

Figure 11. Eighteen months - high contrast control

\section{DISCUSSION}

The aetiology of developmental enamel defects may be congenital, acquired or unknown. Congenital defects such as amelogenesis imperfecta have genetic basis however In the case of acquired defects the aetiology is usually unknown (1). Trauma or excessive use of fluoride can be examples of the known aetiologies. Molar-Incisor Hypomineralisation (MIH) in the case presented is an example of the acquired defects with unknown aetiology (2).

Possible pre, peri and post-natal complications during formation of dental hard tissues, may cause temporary or permanent damages to ameloblasts which may result in enamel defects (3). In cases of MIH, there is hypomineralisation defects on first permanent molars, frequently combined with affected incisors (4). The term "cheese molar" has been used for this specific enamel defects based on this clinical appearance.(5) The color of these enamel defects may seem as creamy-white to yellowish-brown and there is always a clear border between affected and sound enamel tissues(6). Suckling et al. reported a total of $9.9 \%$ of the diagnosed $\mathrm{MIH}$ children gave a history of high fever/fever of unknown origin (7).

Beyond these information there is still no standard treatment which can be recommended for all MIH-affected teeth (8). As the minimally invasive dentistry concept has been accepted also in field of caries management, dentists should avoid operative treatment wherever possible (8). Lygidakis et al. recommended composite resin as the restorative material for fully erupted $\mathrm{MIH}$-affected teeth in children, in long run (9). However, in such cases, as the affected MIH enamel is less sensitive to etching (10-12), which is precisely needed for retention $(13,14)$, the affected enamel should be removed during preparation. William et al. supported that by suggesting removing all affected or discoloured enamel to achieve the best possible adhesion (15). On the contrary, Mathu-Maju and Wright indicated in a 12 months follow up study that the complete removal of affected enamel in 6 to 9 years old children is not justified, even though the value of such short-term clinical studies are limited (16).
In the case presented the discolored, hypomineralysed enamel defects on anterior teeth were removed minimally invasively by using microabrasion technique. Some researches consideres enamel microabrasion, a conservative and non-destructive method, as one of the best treatment options for both intrinsic fluorosis stains and extrinsic superficial enamel stains $(17,18)$. This technique usually causes no postoperative sensitivity (19). In the case two sessions of vital bleaching with $40 \%$ hidrogen peroxide was done on the teeth after microabrasion as some researchers suggested to do vital bleaching after enamel microabrasion since it promotes microreduction of the enamel surface (20). Microabrasioned teeth may develop a darker yellowish shade after the treatment as remaining slightly thinner and translucent enamel surface leads underlying dentin shade to appear more. So, as done in this case, it has been suggested to wait for surface remineralization accompanying with optical improvement of enamel for several weeks after microabrasion therapy before bleaching $(21,22)$.

After microabrasion, the treatment of the teeth was completed using direct composite resin. Despite need for significant clinical time, this method is more conservative compared to indirect options (23). The resin used in this case has supra-nano-size inorganic fillers, that give high mechanical resistance, low polymerization shrinkage value, good polishing and optical properties to the material (2426). Polishing is a clinical key step to maintain color stability as well as the surface roughness of the restoration (2729). Interdental polishing and surface polishing of the restorations were done with recently developed diamond embeded interdental strips and spiral rubber discs in the case presented.

\section{CONCLUSION}

In the case presented, direct composite resin restorations following microabrasion and vital bleaching were done without any preparations. Althought 18 months is still a short time to evaluate, the results indicate that the microabrasion, vital bleaching and direct composite restoration combination can be a promising treatment method for $\mathrm{MIH}$ efected teeth under the conditions of this study.

\section{REFERENCES}

[1] Small BW, Murray JJ. Enamel opacities: prevalence, classifications and aetiological considerations. J Dent 1978;6(1):33-42.

[2] Weerheijm KL, Jälevik B, Alaluusua S. Molar-Incisor hypomineralisation. Caries Res. 2001;35:390-391.

[3] Fagrell TG, Ludvigsson J, Ullbro C, Lundin SA, Koch G. Aetiology of severe demarcated enamel opacities-an evaluation based on prospective medical and social data from 17,000 children. Swed Dent J 2011;35(2):57-66.

[4] Whatling R, Fearne JM. Molar incisor hypomineralization: a study of aetiological factors in a group of UK children. Int J Paediatr Dent 2008;18(3):155-162. 
[5] Van Amerongen WE. Cheese molars: a pilot study of the etiology of hypocalcifications in first permanent molars. ASDC J Dent Child 1995;62(4):266-269.

[6] Suckling GW, Herbison GP, Brown RH. Etiological factors influencing the prevalence of developmental defects of dental enamel in 9-year-old New Zealand children participating in a health and development study. J Dent Res 1987; 66 (9): 14661469.

[7] Kevrekidou A, Kosma I, Arapostathis K, Kotsanos N. Molar incisor hypomineralization of 8 and 14-year-old children: prevalence, severity, and defect characteristics. Pediatr Dent 2015;37(5):455-461.

[8] Ricketts DN, Pitts NB. Traditional operative treatment options. Monogr Oral Sci. 2009;21:164-173.

[9] Lygidakis NA, Wong F, Jalevik B, Vierrou A.M. Alaluusua $\mathrm{S}$, Espelid I. Best clinical practice guidance for clinicians dealing with children presenting with Molar-IncisorHypomineralisation (MIH): an EAPD policy document. Eur Arch Paediatr Dent 2010;11(2):75-81.

[10] Gandhi S, Crawford P, Shellis P. The use of a 'bleach-etch-seal' deproteinization technique on $\mathrm{MIH}$ affected enamel. Int J Paediatr Dent 2012;22(6):427-434.

[11] Natarajan AK, Fraser SJ, Swain MV, Drummond BK, Gordon KC. Raman spectroscopic characterisation of resin-infiltrated hypomineralised enamel. Anal Bioanal Chem 2015;407(19):5661-5671.

[12] Bozal CB, Kaplan A, Ortolani A, Silvina GC, Biondi AM. Ultrastructure of the surface of dental enamel with molar incisor hypomineralization $(\mathrm{MIH})$ with and without acid etching. Acta Odontol Latinoam. 2015;28(2):192-198.

[13] Kotsanos N, Kaklamanos EG, Arapostathis K. Treatment management of first permanent molars in children with MolarIncisor Hypomineralisation. Eur J Paediatr Dent 2005;4:179184.

[14] William V, Messer LB, Burrow MF. Molar incisor hypomineralization: review and recommendations for clinical management. Pediatr Dent 2006;28(3):224-232.

[15] Mathu-Muju K, Wright JT. Diagnosis and treatment of molar incisor hypomineralization. Compend Contin Educ Dent 2006;27(11):604-610.

[16] Fragelli CM, Souza JF, Jeremias F, Cordeiro R, Santos-Pinto L. Molar incisor hypomineralization $(\mathrm{MIH})$ : conservative treatment management to restore affected teeth. Braz Oral Res 2015;29(1):1-7.
[17] Welbury RR, Carter NE. The hydrochloric acid-pumice microabrasion technique in the treatment of post-orthodontic decalcification. Br J Orthod 1993;20(3):181-185.

[18] Ashkenazi M, Sarnat H. Microabrasion of teeth with discoloration resembling hypomaturation enamel defects: four year follow up. J Clin Pediatr Dent 2000;25(1):29-34.

[19] Wray A, Welbury R. UK National clinical guidelines in paediatric Dentistry: treatment of intrinsic discoloration in permanent anterior teeth in children and adolescents. Int J Paediatr Dent 2001;11(4):309-315.

[20] Celik EU, Yildiz G, Yazkan B. Comparison of enamel microabrasion with a combined approach to the esthetic management of fluorosed teeth. Oper Dent 2013;38(5):134143.

[21] Sundfeld RH, Croll TP, Briso ALAlexandre RS, Neto DS. Considerations about enamel microabrasion after 18 years. Am J Dent 2007;20(2):67-72.

[22] Briso A, Lima A, Goncalves R, Gallinari MO, Dos Santos PH. Transenamel and transdentinal penetration of hydrogen peroxide applied to cracked or microabrasioned enamel. Oper Dent. 2014;39(2):166-173.

[23] Demarco FF, Collares K, Coelho-de-Souza FH. Anterior composite restorations: a systematic review on long-term survival and reasons for failure. Dent Mater. 2015;31(10):12141224.

[24] Ferracane JL. Resin composite-state of the art. Dent Mater. 2011;27(1):29-38.

[25] Chen MH. Update on dental nanocomposites. J Dent Res. 2010;89(6):549-560.

[26] Curtis AR, Palin WM, Fleming GJ, Shortall AC, Marquis PM. The mechanical properties of nanofilled resin-based composites: the impact of dry and wet cyclic pre-loading on bi-axial flexure strength. Dent Mater. 2009;25(2):188-197.

[27] Madhyastha PS, Naik DG, Srikant N, Kotian R, Lyer SS. Effect of finishing/polishing techniques and time on surface roughness of silorane and methacrylate based restorative materials. Oral Health Dent Manag. 2015;14(4):212-218.

[28] Avsar A, Yuzbasioglu E, Sarac D. The effect of finishing and polishing techniques on the surface roughness and the color of nanocomposite resin restorative materials. Adv Clin Exp Med. 2015;24(5):881-890.

[29] Chour RG, Moda A, Arora A, Arafath MY, Shetty VK., Rishal Y. Comparative evaluation; of effect of different polishing systems on surface roughness of composite resin: an in vitro study. J Int Soc Prev Community Dent. 2016;6(2):166-170. 